\title{
The Relevance and Practice of Theological Education: A Case Study of Charismatic Churches in Santasi-Heman, Ghana
}

Samuel Anyan Ewool, Paul Kang-Ewala Diboro

To Link this Article: http://dx.doi.org/10.6007/IJARBSS/v11-i10/10965

DOI:10.6007/IJARBSS/v11-i10/10965

Received: 04 August 2021, Revised: 29 August 2021, Accepted: 17 September 2021

Published Online: 05 October 2021

In-Text Citation: (Ewool \& Diboro, 2021)

To Cite this Article: Ewool, S. A., \& Diboro, P. K.-E. (2021). The Relevance and Practice of Theological Education: A Case Study of Charismatic Churches in Santasi-Heman, Ghana. International Journal of Academic Research in Business and Social Sciences, 11(10), 157-174.

Copyright: (c) 2021 The Author(s)

Published by Human Resource Management Academic Research Society (www.hrmars.com)

This article is published under the Creative Commons Attribution (CC BY 4.0) license. Anyone may reproduce, distribute, translate and create derivative works of this article (for both commercial and non-commercial purposes), subject to full attribution to the original publication and authors. The full terms of this license may be seen at: http://creativecommons.org/licences/by/4.0/legalcode

\section{Vol. 11, No. 10, 2021, Pg. 157 - 174}

Full Terms \& Conditions of access and use can be found at http://hrmars.com/index.php/pages/detail/publication-ethics 


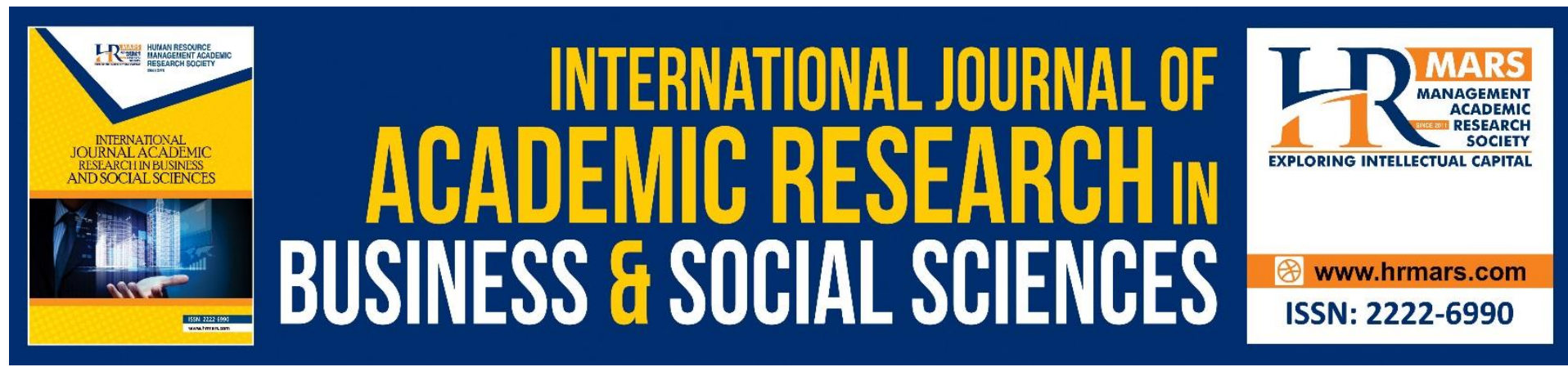

\title{
The Relevance and Practice of Theological Education: A Case Study of Charismatic Churches in Santasi-Heman, Ghana
}

\author{
Samuel Anyan Ewool, Paul Kang-Ewala Diboro \\ Department of Theology, Christian Service University College, P. O. Box KS 3110, Kumasi, \\ Ghana \\ Email: samuelaewool@gmail.com, pdiboro@csuc.edu.gh/ewaladiboro@gmail.com
}

\begin{abstract}
Theology involves education which is an instrument and structure for securing the future of the Church. Establishment of ground rules on how theological studies can be used as a tool for the benefit of practical ministry in transforming the church and society as a whole is indeed crucial. This study report therefore investigates the relevance of theological studies for practical ministry. It considers the extent to which church ministers, pastors and leaders apply their theological knowledge in ministerial practices. The study adopted a quantitative and qualitative research approach to examine and explain the data obtained. Most of the respondents had some knowledge in theological education and were practicing it. However, the study indicated that those with little or no knowledge in theological education may not have attended formal Bible schools where proper theology is taught and this could affect their church growth, societal development and transformation. To improve upon the quality of the life of the church members holistically, the study suggests that, theological education is relevant for practical ministry through knowledge in theology and its practice. The study further highlights the need for a more informed theological education of ministers and leaders of churches in order to conduct their activities in such a way that can impact society. It recommends that, proper theological education and reliance on the Holy Spirit should be mutually engaged for a total development and transformation of our societies.
\end{abstract}

Keywords: Religion, Transformation, Human Behavior, Theology, Charismatic Churches

\section{Introduction}

Theology is the rational and systematic study of God and religious beliefs. It is also an academic discipline in most seminaries and universities. Concerns about God keep rising in every strata of human endeavor and in recent times, the study of God and religion are needed to answer certain questions on the minds of people. They normally ask why bad things happen in the world among others especially in times of a pandemic where nations are put on a siege if God exists. Religion has to do with beliefs and it is in the nature of every person to believe something. This unique feature in people, directly or indirectly affect human behavior. Ministers of the gospel then must be able to systematically present God to their followers in a way that they will understand and appreciate. The rapid change in societal systems calls for 
in depth knowledge on God and beliefs which consequently affect the relevance of any ministry in our world today. Also, the breach of sound doctrine and ministerial ethics among some ministers and ministries in our world today especially, in the modern charismatic churches is of great concern. Establishment of ground rules on how theological studies can be used as a tool for the benefit of practical ministry in transforming the church and society as a whole is indeed crucial.

Africa is the second largest continent in the world. Andrew Walls, a Scottish missiologist, drew attention to the fact that Christianity is becoming very important in Africa as the heartlands of the Church are no longer in Europe and decreasing in North America. Walls (1976) goes on to draw a conclusion that: "Theology that matters will be theology where the Christians are and as such what happens within the African Churches in the next generation will determine the whole shape of Church history for centuries to come. Walls (1976), further argues that what world evangelization is carried on may well be determined by what goes on in Africa. In addition to this, what sort of theology that will most characterize Christianity of the twentyfirst century may well depend on what has happened in the minds of African Churches in the interim. Gathogo (2013) argues that there is a strong basis for studying the birth and development of Christian education in Africa today because of the fact that the numerical centre of Christian gravity has shifted to Africa; for indeed, Africa is portrayed as the most Christian Continent in the twenty-first century. Theological education which forms a crucial part of Christian education needs attention and careful investigation (Gathogo, 2013) but less work on this history is reported Rowdon (1971). All throughout the history of the Church there have been several attempts by ministers to provide theological education for new ministers. In Ghana, there are many ministers and ministries coming up who do not have any sound theological education as foundation.

In recent times, sound theological and ethical issues have become the concern of some Christian leaders among Charismatic churches. The proliferation of charismatic churches calls for a crucial attention. Charlatans are perverting the gospel because of the love of money. Scholars have identified that the effects of prosperity Gospel in modern African Christianity is a major cause of the proliferation of new charismatic movements (Anim, 2010). Whilst some ministers see the need for theological education, others feel ministry is all about the call of God and as such once there is a calling one should just begin the ministry, depend on the Holy Spirit and learn on the job. Theological education is thus undermined by some charismatic church leaders. Some of those who attempt to have some level of training settle for just mere mentors whose theological basis cannot be readily accredited because they also might not have had any theological education. This study report therefore investigates the relevance of theological education for practical ministry among some charismatic churches.

The objectives of this study report are to:

- Assess the extent to which church Ministers/Pastors/leaders are knowledgeable in theological education.

- Assess the extent to which church Ministers/Pastors/leaders are practicing theological education.

- Assess the relevance of theological education for practical ministry.

\section{Literature Review \\ Theology}

According to Boesak (1978) theology is a critical reflection on society and the life of the Church. Theology is from two Greek words; "theos" which means God and "logos" which 
means word, hence theology can also be simply defined as the study of the word of God, the word about God and the word by God. Although the logos part in the word 'theology' signals rational processes, it is equally crucial to insist that "a theologian is born by living, nay dying and being damned, not by thinking, reading and speculation" (Hazilit, 2004).There are many types of theology depending on the focus and scope of classification. For instance, in terms of religion there can be Christian theology, Islamic theology, Buddhist theology, Hinduist theology among others. So considering Christian Theology, there are also many types of theologies. Examples are Biblical theology, Pauline theology, the theology of Peter, Old Testament theology, New Testament theology, etc.

\section{Theological Education}

African scholars have defined education as community's way of passing on her accumulated knowledge and insights to its members to enable them ensure the continuity of the community (Pobee \& Hallencreutz, 1986). Wolterstorff and Stronks (2002) argue that the church like any other community with a cause and lifestyle of its own finds it necessary to educate its new recruits. Theological education is a subset of Christian education. Wolterstorff and Stronks (2002) define Christian education as education by the Christian community for the Christian community. This implies the essential uniqueness of Christian education. Theological education deals with aspects of Christian education that focus on God, man and environment and their interrelationship. Mugambi (1989) defines theological education as the institutionalized process through which the theologians of a particular religion are trained. Wingate (2005) reports that, theological education is a lifelong process which does not end till one leaves the earth and that it involves a critical union of context, tradition, skills and experience

\section{The Concept of Theological Education}

The concept of theological education can be traced way back from the Old Testament and as such Walls (2013) rightly puts it that "the Old Testament is not only the first textbook of Church history but it is the oldest programme of theological education on record". In the Exodus of the people of Israel, God instructed the family heads to teach the children the precepts of God and this was to be passed on from one generation to another. Pockets of theological education were observed with the school of the Prophets in the book of Kings. By the time of Jesus, different sects and rabbinic schools were established to teach things concerning God and His word. For instance, although there were flaws in the theological education of the Pharisees and the Sadducees, they were doctors of the law with a sole aim of preserving the ordinances in the law. Early Rabbinic schools in the last century BC and first century AD like the school of Hillel and Shammai were also schools which engaged in scholarly arguments on theology, ethics and ritual practices and these contributed significantly to developing present day Judaism. Even the master Jesus also had some sort of theological education for his disciples. In many instances in the gospels, they came to Him privately for further explanations on His teachings. The early church (about the first four centuries) also had some theological education occurring around that time. Initially, there was little concern about formal theological training because the apostolic age was characterized by the prevalence of charismatic gifts and also the nature of the charismatic ministry of the early church fathers. In the first part of the second century when monepiscopacy started springing up, it brought some level of attention to formal ministerial training. Sub-divisions in the 
clerical orders also led to the regularization of clerical training where one needed to be tested and proven before promoted to a higher order.

Rowdon (1971), reports that Bishop Cyprian of Carthage in the third century did not promote anyone without an examination. The need for formal theological education grew along the second century where the church was troubled by scholarly debates from pagans, Jews and heretical schools like the Gnostics and it needed to have a strong acknowledgement of its doctrines and the canon of scripture. The Catechetical school of Alexandria which was founded by Bishop Demetrius and was led by Origen was the first theological school. Its domain was summarized as 'an encyclopaedic teaching, presenting in the first place the whole series of profane sciences, and then rising to moral and religious philosophy, and Christian theology finally, set forth on the sacred books in the form of a commentary. In the early medieval period that is from AD500- AD1000, the church faced with the task to convert barbarians ushered in monasteries as centers for learning (Rowdon, 1971). The later middle ages (AD 1000- AD 1500) was when Europe was shallowly Christianized and the pope and the emperor were the final authorities of the church and the state and this brought in concerns of secularization affecting the church. Priests and Bishops could teach in towns and villages and universities begun to spring up and in a way it was influenced by the responsibilities of priests and bishops to provide clerical training (Rowdon, 1971). The reformation period saw the emergence of Calvin's Academy, Cambridge and other universities with theological education. The smaller seminaries provided general education whereas the greater seminaries supported ministerial training. Theological education continued on and on after the reformation period and in the $19^{\text {th }}$ century theological colleges begun to spring up and theological education is still going on today with different institutions and colleges being established (Rowdon, 1971).

\section{Theological Education in Africa}

It was reported by Pobee (2013) that theological education in Africa continuing to be an issue and it indicates how far theology has truly engaged the African continent. Africa is an example of the birthing of serious attempts by theology in Africa to engage the African environment which is pluralistic, and has not the luxury of a Christendom ideology which shaped theological construction in the West. He argues, that it is demanded of Africans to take ownership of the project of theological education. Pobee (1990) also reports that Archbishop Walter Khotso Makhulu of the Church of Province of Central Africa (another African Anglican Church leader), highlights "there is an urgent need for efforts to be made through which African Church leaders may take 'ownership' of the opportunities for training of God's people and act as facilitators and mentors, enabling such training to take place". Also, Okolo (1991) contends that despite the high statistics associated with seminarians in Africa, the important thing is not how many indigenous seminaries and Priests Africa produce each year, but the kind of training and education given to them. Crucial curriculum consideration should be looked at in various Bible schools that offer any form of theological education. He stresses on the fact that quality not quantity becomes decisive in realizing the main objectives of African theology and as such it is important that those who train and educate seminarians of Africans plan the curriculum in theology and philosophy having at the background of their minds the African situation and experience. 


\section{Ministry}

Ministry which is derived from the Greek word "diakonia" basically means service to God, the church and the society. The church which includes every member of the body of Christ is called to do the work of the ministry; that is, the "raison d'etre" of the church is ministry (Morrison, 2019). Tidball (1986) argues that, the ministry of God to His people in the Old Testament is the foundation for understanding ministry, all of which belongs to God (Anderson, 1999). According to Dunn (1977), "the fundamental ministry is Christ's own ministry, whose goal is to reconcile all people to God and to each other and to bring them into a new family where they can freely live and grow together as children of God. Again, Jesus was purely God's incarnational ministry, since He came as the true image of God. The church as the body of Christ fundamentally is to continue the ministry of Christ. Every Christian is ordained to serve in the ministry of Christ and as observed by Anderson (2013) the basic ordination for the Christian is baptism. This means that anyone who believes in Jesus joins the community of believers. The church then fulfills God's dream of having people from all walks of life coming into the knowledge of him. The ministry of the church then is multifaceted and O'Meara (1983) defines it as "doing something for the advent of the kingdom in public on behalf of a Christian community which is a gift received in faith, baptism or ordination and which is an activity with its own limits and identity within a diversity of ministerial actions". The goal is that wherever every Christian goes he/she is in ministry with the objective of transforming human behavior and society at large. For instance, the Christian medical doctor should not only see his profession to only treat the sick but must ensure Christ is revealed in the hospital and this principle must run through the entire ministry of the church. The word "ekklesia" (the church) is used in the New Testament in reference to the believing community and this term basically means "the called out ones". This means that no matter the background of the individual, to be in Christ is to be among God's people. The church which includes every member of the body of Christ is called to do the work of the ministry. The church functionally can be seen in the light of the apostolic (the Church's consciousness of being sent into the world to make disciples), the sacrificial (service to God and man) and the charismatic (the consciousness of the grace and power of the Spirit) (Asante, 2002). However, the place of the specially ordained ministry cannot be undermined since it involves people who have been called by God, ordained in or by the church and commissioned to a lifelong ministry to the church and the world. The ordained ministry serves as the representative ministry that facilitates and manages the ministry of the church which is multifaceted. As such, the ordained ministry seeks to equip the saints, for the work of the ministry.

\section{Practical Ministry}

It has already been established that every Christian no matter his/her profession is ordained for the ministry but there are aspects of the ministry that are directly associated with the church setting and this is commonly known as practical ministry. Practical ministry consists of the activities that run through the assembling together of Christians and the direct evangelical advances as in missions. Warren (1995) observes that "a church without a purpose and mission eventually becomes a museum-piece of yesterday's traditions". One key aspect of this mission is evangelism. Evangelism simply is presenting the gospel to unbelievers with the aim of bringing them to the saving knowledge of Jesus Christ. It was reported by Green (1984) that Archbishop William Temple during the period of world war II defined evangelism as presenting Christ in the power of the Holy Spirit that men may come to put their faith in God 
through him, to accept him as their saviour and to serve him as their King in the fellowship of his church" and this forms a major part of the church's practical ministry.

\section{Charismatic Churches}

Few events have affected the church in the twentieth century as greatly as the Azuza Street revival of the 1906-9 in Los Angeles led by the black evangelist William J. Seymour, which alleged to have ushered in the Pentecostal renewal (Hollenweger, 1997). Anim (2021) reports that from Azuza Street, the Pentecostal movement is alleged to have spread to other parts of America and crossed the Atlantic. By 1909 the movement is thought to have spread to Latin America, India and Korea. After the $2^{\text {nd }}$ World War, the movement spread to Africa and other third countries. Anim (2021) argues that various Pentecostal and Charismatic movements emerged in history all in an attempt not only to preserve but also to restore the spirit of the New Testament and the apostolic faith in the changing conditions of each ensuing generation. Pentecostalism in all diversity is by far the most important religious trend in Ghana today. The Ghana Pentecostal Council (GPC) currently has over sixty-six member denominations with some emerging from the Charismatic tradition (Anim, 2021). In Ghana the term Pentecostal is usually used to label the older or classical Pentecostal churches such as the Assemblies of God and the Christ Apostolic Churches whilst the terms neo-Pentecostal and Charismatic may be referred to the independent "full gospel" ministries or churches. These Charismatic churches usually have links with or are inspired by American faith preachers such as Oral Roberts, Kennth Hagin, Fred Price, Kenneth and Gloria Copeland, etc. (Anim, 2021). Pentecostals usually describe their churches as 'full Gospel', meaning that "believers are 'filled with the Holy Spirit' in a way that was promised to the early Christians in the Gospels and other books of the New Testament (Brouwer, Gifford, \& Susan, 2013)". Pentecostals for example are characterized by being "born again" and experiencing in a more personal way the relationship between the believer and Jesus Christ. The Charismatics believe God's sacred words and divine power are available to each believer in the text of the Bible and the appropriation of Spiritual gifts, Charismata for the efficacy of the church. Charismatic Christianity emphasizes on the Holy Spirit and His work, spiritual gifts and miracles as part of the everyday life of the believer. Charismatic Christianity is commonly known as Spirit-filled Christianity. Charismatic churches came out of the Pentecostal movements and as such are sometimes referred to as Neo-Pentecostals. Meyer (2004), reports that, since the 1980s, Pentecostal-charismatic Christianity has grown intensely in Sub-Saharan Africa. Hackett (1998) has shown that born-again Charismatic Christians in Ghana and Nigeria have a particular affinity with the electronic media and have transformed the religious landscape of the respective nations. Larbi (2001) argues that Pentecostal-Charismatic churches depict the growing edges of Christianity in its most vital and dynamic forms and he maintains that, it is within these groups, more than any other that one sees vitality, growth, creativity and freshness in the adherents' understanding and application of the divine revelation to the needs, fears and aspirations of the people'.

\section{Methodology}

\section{Study Location}

The study was conducted in Santasi-Heman in the Atwima Kwanwoma District of Ghana. The town has a population of about one thousand five hundred (1500) with Eight (8) charismatic Churches presently existing. 


\section{Research Design}

This study adopted a quantitative and qualitative research approach which allowed the researchers to use descriptive analysis (including frequencies) to examine and explain the data obtained from the respondents regarding their demographic background and responses to the interview questions posed.

\section{Data Collection Procedures}

The study focused on the aspects of ministry directly associated with the church setting. Hence only Ministers, Pastors or Church leaders were interviewed. A structured interview with closed-ended questions were used and administered face to face with the respondent (Appendix 1). A standardized list of questions was used and each respondent was asked the same questions in the same order (Appendix 1). The first set of questions was to find out the background information of respondents. Objective of the second series of questions was to determine how knowledgeable Pastors/Ministers/Leaders are in Theological Education. The third series of questions aimed at the extent of practicing theological education. Finally, the last set of questions was to assess the relevance of theological education on practical ministry (Appendix 1). The likert scale used for the responses to the questions was indicated as follows: $(1)=$ To a very great extent, $(2)=$ To a great extent, $(3)=$ To a moderate extent, $(4)=$ To a little extent, $(5)=$ Not at all.

\section{Data Analysis}

Data were entered and analyzed using Statistical Package for Social Sciences (SPSS) software version 16. Demographic and Frequency table of the various assessments were obtained.

\section{Results and Discussion \\ Demographic}

Eight male Pastors made up of a Bishop, three Reverend Ministers, a pastor, an apostle and two Prophets between 26-60 years were interviewed. Three of them were with their diplomas and another three with Bachelors, Masters and PhD. The other two have Junior High School and Senior High School certificates as their highest level of education. However, $50 \%$ of them have their diplomas in Theology while the rest have either Bachelors or certificate with one of them having no theological education level. Six of the respondents indicating $75 \%$ have 6 $15 y e a r s$ experience in the work of Ministry with $25 \%$ having more than 16 years of experience in the Ministry (Appendix 2).

\section{Extent to which Church Ministers/Pastors/Leaders were knowledgeable in theological education}

Responses from respondents regarding the extent to which church Ministers/Pastors/Leaders were knowledgeable in theological education are presented in Table 1. The results indicated that Five to seven out of the eight respondents representing $62.5-87.5 \%$ had some knowledge in theological education. Thus, they understood the term theological education, studied some theology before starting practical ministry and somehow their leaders had some knowledge in theology. In addition, they had some knowledge in church history with some basic understanding of biblical studies, hermeneutics, exegesis, homiletics and ethics. These responses were in agreement with report by Werner (2010), from World Council of Churches that theological education is the most essential key and strategic factor for the renewal of the churches life and mission. They noted that without proper and relevant theological education, 
the very future of the Christian church, its dialogue with society and its participation in the daily struggles and longings of the common people may be in danger. The future of Christianity will be left to those who promote a distorted image of Christian identity and endanger dialogue and co-existence with other churches as well as other religious traditions when churches and their leaders invest less in theological education. They further noted that theological education plays a very important role in the transferring of Christian tradition from one generation to the other.

Theological education is a matter of survival for an authentic and contextual mission of the church in contemporary contexts. For example there is co-existence of the church and society living at peace and as one family. This has become a commonly held conviction both in western and eastern Christianity, in both the churches of the South and the churches of the North. The role of theological education is never limited just to the training of Christian ministers. With all legitimate attention and emphasis on ministerial formation, the road and inclusive approach emphasizing theological education as a process of renewal and formation for all God's people always needs to be kept in mind. Theological education is not only serving the building up of the church, but also is creating social awareness, political discernment, social involvement and Christian participation in transformation processes of societies. Thus investing in theological education is a direct investment also into social and political development and transformation of society and the raising of its educational levels (Werner, 2010).

Table 1. Responses to Knowledge in Theological Education

\begin{tabular}{|c|c|c|c|c|c|c|c|c|c|c|c|c|c|c|c|c|c|c|}
\hline & 1 & & & 2 & & 3 & & 4 & & 5 & & 6 & & 7 & & 8 & & 9 \\
\hline Responses & $\begin{array}{l}\mathrm{Fr} \\
\mathrm{e} \\
\mathrm{q}\end{array}$ & $\%$ & $\begin{array}{l}\text { Fre } \\
q\end{array}$ & $\%$ & $\begin{array}{l}\text { Fre } \\
q\end{array}$ & $\%$ & $\begin{array}{l}\text { Fre } \\
q\end{array}$ & $\%$ & $\begin{array}{l}\text { Fre } \\
q\end{array}$ & $\%$ & $\begin{array}{l}F \\
r \\
e \\
q\end{array}$ & $\%$ & $\begin{array}{l}\text { Fre } \\
q\end{array}$ & $\%$ & $\begin{array}{l}\text { Fre } \\
q\end{array}$ & $\%$ & $\begin{array}{l}\text { Fre } \\
q\end{array}$ & $\%$ \\
\hline $\begin{array}{l}\text { very great } \\
\text { extent }\end{array}$ & 3 & $\begin{array}{l}37 . \\
5 \\
\end{array}$ & 1 & $\begin{array}{l}12 . \\
5 \\
\end{array}$ & 0 & 0.0 & 3 & $\begin{array}{l}37 . \\
5 \\
\end{array}$ & 0 & 0.0 & 2 & $\begin{array}{l}25 . \\
0\end{array}$ & 2 & $\begin{array}{l}25 . \\
0\end{array}$ & 3 & $\begin{array}{l}37 . \\
5\end{array}$ & 4 & $\begin{array}{l}50 . \\
0\end{array}$ \\
\hline $\begin{array}{l}\text { great } \\
\text { extent }\end{array}$ & 1 & $\begin{array}{l}12 . \\
5\end{array}$ & 3 & $\begin{array}{l}37 . \\
5\end{array}$ & 2 & $\begin{array}{l}25 . \\
0\end{array}$ & 2 & $\begin{array}{l}25 . \\
0\end{array}$ & 1 & $\begin{array}{l}12 . \\
5\end{array}$ & 2 & $\begin{array}{l}25 . \\
0\end{array}$ & 1 & $\begin{array}{l}12 . \\
5\end{array}$ & 1 & $\begin{array}{l}12 . \\
5\end{array}$ & 3 & $\begin{array}{l}37 . \\
5\end{array}$ \\
\hline $\begin{array}{l}\text { moderate } \\
\text { extent }\end{array}$ & 2 & $\begin{array}{l}25 . \\
0 \\
\end{array}$ & 2 & $\begin{array}{l}25 . \\
0\end{array}$ & 4 & $\begin{array}{l}50 . \\
0\end{array}$ & 1 & $\begin{array}{l}12 . \\
5\end{array}$ & 2 & $\begin{array}{l}25 . \\
0 \\
\end{array}$ & 1 & $\begin{array}{l}12 . \\
5 \\
\end{array}$ & 2 & $\begin{array}{l}25 . \\
0 \\
\end{array}$ & 2 & $\begin{array}{l}25 . \\
0\end{array}$ & 0 & 0.0 \\
\hline $\begin{array}{l}\text { little } \\
\text { extent }\end{array}$ & 1 & $\begin{array}{l}12 . \\
5\end{array}$ & 1 & $\begin{array}{l}12 . \\
5\end{array}$ & 1 & $\begin{array}{l}12 . \\
5\end{array}$ & 1 & $\begin{array}{l}12 . \\
5\end{array}$ & 4 & $\begin{array}{l}50 . \\
0\end{array}$ & 0 & 0.0 & 0 & 0.0 & 0 & 0.0 & 0 & 0.0 \\
\hline not at all & 1 & $\begin{array}{l}12 . \\
5\end{array}$ & 1 & $\begin{array}{l}12 . \\
5\end{array}$ & 1 & $\begin{array}{l}12 . \\
5\end{array}$ & 1 & $\begin{array}{l}12 . \\
5\end{array}$ & 1 & $\begin{array}{l}12 . \\
5\end{array}$ & 3 & $\begin{array}{l}37 . \\
5\end{array}$ & 3 & $\begin{array}{l}37 . \\
5\end{array}$ & 2 & $\begin{array}{l}25 . \\
0\end{array}$ & 1 & $\begin{array}{l}12 . \\
5\end{array}$ \\
\hline Total & 8 & $\begin{array}{l}10 \\
0\end{array}$ & 8 & $\begin{array}{l}10 \\
0\end{array}$ & 8 & $\begin{array}{l}10 \\
0\end{array}$ & 8 & $\begin{array}{l}10 \\
0\end{array}$ & 8 & $\begin{array}{l}10 \\
0\end{array}$ & 8 & $\begin{array}{l}10 \\
0\end{array}$ & 8 & $\begin{array}{l}10 \\
0\end{array}$ & 8 & $\begin{array}{l}10 \\
0\end{array}$ & 8 & $\begin{array}{l}10 \\
0\end{array}$ \\
\hline
\end{tabular}

1=How do you understand the term theological education? 2= Did you study theology before starting practical ministry? $3=$ How knowledgeable are other leaders of your church in theology? 4= Are you familiar with Biblical studies as a basic type of Christian theology? 5= Are you familiar with church history as a subject in Christian theology? $6=$ Do you understand the term Hermeneutics? 7= Do you understand the term Exegesis? 8= Are you familiar with the term Homiletics? 9= Are you familiar with Ministerial Ethics? 
The results indicated five to seven out of the eight respondents representing $62.5-87.5 \%$ who were practicing theological education in their ministries indicated by inclusion in their church programmes Bible studies, Bible expositions, Bible text studies, Bible character studies, Church history, Christian leadership and Theology of Ministry (Table 2). These studies according to the respondents could contribute to societal development and transformation. The responses were in agreement with Mumo (2013) who indicated that Bible studies in church services which are sometimes referred to as Sunday schools are relevant in theological education because they equip prospective students of theological education with basic knowledge on which they base their theological articulation. Prospective students of theological education consist of church leaders and ministers who have not had any form of theological education. Elim Pentecostal Church calls such ministers as Ministers in training (MIT) and they argue that this is an important time of preparation for the lifetime of ministry. The few (1-3 persons representing 12.5-37.5\%) who may not be practicing theological education however, may be concentrating on prophetic and deliverance services as observed by Anderson (2013) who noted that as far as they are concerned 'the Spirit makes and equips teachers, is an active participant in their development and is the one who enables them to change in a changing world'. In addition, Resane (2016) argues that in the Neo-Pentecostal Charismatics' case, the biblical statements, principles, passages or ideas are at disposal for this careful scrutiny, without employing historical context or hermeneutical principles. The biblical data must be accepted as such. What is written is literally accepted as the interpretation and no metaphysical explanation is given. This implies that the biblical data (phenomenon) must speak for itself and all theoretical knowledge, assumptions, and beliefs should be put aside (Resane, 2016).This may result in random dipping or wholesale adoption in establishing doctrines.

\section{Assessing the Relevance of Theological Education on Practical Ministry}

Results of assessment of the relevance of theological education on practical ministry are presented in Table 3. Responses from respondents indicated that 5-8 of them representing $62.5-100 \%$ of the respondents agreed that theological education was relevant to practical ministry. They ascertained that theological education could promote sound teachings, enhance good ministerial ethics, influence evangelism and missions, promote church growth and inform them about church history. This is in agreement with Aboagye (2018) who pointed out that theological education and the anointing of the Holy Spirit could complement each other for the benefit of both clergy and congregants. He emphasizes that formal theological education and the anointing of the Holy Spirit must be mutually engaged. However, 1-3 out of the eight respondents representing $12.5-37.5 \%$ refuted the claim that Pastors/Ministers/Leaders who have had some form of theological education can preach or teach better than those who have not had any theological education (Table 3). They attributed this claim to charismata (divine endowments by the Holy Spirit) as suggested by Woodbridge (1994) who argues that the pneumatological penchant of Pentecostals is wellknown: their constant reliance on the Holy Spirit, who would teach them all things in Jesus' absence, who would facilitate 'greater works' than Jesus himself performed, who would grant a 'word of knowledge' understood as divinely originated disclosures of hidden information, and whose empowerment would result in accompanying signs. 
Table 3. Assessing the relevance of Theological Education on Practical Ministry

\begin{tabular}{|c|c|c|c|c|c|c|c|c|c|c|c|c|c|c|}
\hline \multirow{2}{*}{ Responses } & \multicolumn{2}{|l|}{1} & \multicolumn{2}{|l|}{2} & \multicolumn{2}{|l|}{3} & \multicolumn{2}{|l|}{4} & \multicolumn{2}{|l|}{5} & \multicolumn{2}{|l|}{6} & \multicolumn{2}{|l|}{7} \\
\hline & Freq & $\%$ & Freq & $\%$ & Freq & $\%$ & Freq & $\%$ & Freq & $\%$ & Freq & $\%$ & Freq & $\%$ \\
\hline $\begin{array}{l}\text { very great } \\
\text { extent }\end{array}$ & 6 & 75.0 & 5 & 62.5 & 5 & 62.5 & 6 & 75.0 & 4 & 50.0 & 3 & 37.5 & 3 & 37.5 \\
\hline $\begin{array}{l}\text { great } \\
\text { extent }\end{array}$ & 1 & 12.5 & 2 & 25.0 & 2 & 25.0 & 1 & 12.5 & 2 & 25.0 & 2 & 25.0 & 0 & 0.0 \\
\hline $\begin{array}{l}\text { moderate } \\
\text { extent }\end{array}$ & 0 & 0.0 & 0 & 0.0 & 0 & 0.0 & 1 & 12.5 & 0 & 0.0 & 3 & 37.5 & 2 & 25.0 \\
\hline $\begin{array}{l}\text { little } \\
\text { extent }\end{array}$ & 0 & 0.0 & 0 & 0.0 & 0 & 0.0 & 0 & 0.0 & 1 & 12.5 & 0 & 0.0 & 0 & 0.0 \\
\hline not at all & 1 & 12.5 & 1 & 12.5 & 1 & 12.5 & 0 & 0.0 & 1 & 12.5 & 0 & 0.0 & 3 & 37.5 \\
\hline Total & 8 & 100 & 8 & 100 & 8 & 100 & 8 & 100 & 8 & 100 & 8 & 100 & 8 & 100 \\
\hline
\end{tabular}

$1=$ Theological education can promote sound teachings. $2=$ Does theological education enhance good ministerial ethics? 3= Theological education can influence evangelism and missions. 4= Can theological education promote church growth? $5=$ Does theological education inform pastors/leaders/ministers about church history? $6=$ Theological education can promote societal development and transformation. 7= Do Pastors/Ministers/Leaders who have had any form of theological education preach/teach better than those who have not had any theological education?

\section{Conclusions, Recommendations \& Suggestions for Future Research}

This study investigated the relevance and practice of theological education among charismatic churches in Santasi-Heman, Ghana. It was concluded from the studies that theological education is relevant through knowledge in theology and its practice. This could positively improve the quality of life of the church members and make them conduct themselves better. The society could then be impacted through the sharing of this knowledge which will lead to societal development and transformation. It was also noted from the study that some pastors had little or no knowledge in theology and this could affect their church growth and societal development and transformation. However, these were of the opinion that they were in a charismatic and prophetic era and that theological education may not be necessary in influencing one's ability to do the work of God as they are assured of the role of the Holy Spirit. It can thus be recommended from the study that theology and reliance on the Holy Spirit should be mutually engaged for a total development and transformation in our societies. It was observed from the study that what is taught is very crucial for proper theology not just the high number of theological institutions. Thus, research into the quality of teaching and the curriculum for theology in various theological institutions is recommended in further studies. Future research could be extended to other communities.

\section{Theoretical and contextual contribution of this research to existing knowledge}

Societal changes in recent times, call for a more informed theological education of ministers and leaders of churches in order to conduct their activities in such a way that they can impact on society. For example, some ministers and leaders have little or no idea of the ethics of 
ministerial work and misconduct themselves while most of their members also follow suit. Theological studies can be a useful tool for practical ministry in transforming the church and society as a whole. Whilst some ministers and leaders see the urgent need for theological education, others feel it is not necessary since they can solely depend on the Holy Spirit who they believe is their teacher. Theological education is thus not considered so important for some charismatic church leaders and for that matter the anticipated societal change is not realized. This study thus provides information that can help Ministers, Pastors and Leaders appreciate the need to adopt theological education in their churches/ministries in order to bring about total transformation of the church members and with its application and impacts make members practical Christians and ultimately bring about the desired societal transformation.

\section{Limitations of the Study}

Time and financial constraints did not allow the consideration of several other charismatic churches outside the location.

\section{Acknowledgement}

We wish to thank all the lecturers especially Dr. Samuel B. Adubofuor, Head of Theology Department, Rev. Emmanuel Twumasi Ankrah, Programmes Coordinator and Pastor Baffour Awuah who collectively assisted the corresponding author in his training at Christian Service University College. We are grateful to the entire staff of the Department of Theology and all others who advised us in the field of research and for their immense contribution towards the completion of this work. Lastly, we are grateful to Dr. Manfred B. Ewool formerly of CSIRCrops Research Institute and presently the founder and Head Pastor of Blessed Jesus World Church, Santasi-Heman and his wife Mrs. Felicia Ewool as well as Rev. Dr. Albert B. Kwabi \& wife Mrs. Theresa Kwabi for their financial support in the conduct and publication of this study.

\section{References}

Aboagye, D. N. A. (2018). Academic versus spiritual: Theological education and the anointing of the Holy Spirit in contemporary prophetic ministries in Ghana. Journal of Contemporary Ministry, (4), 61-77.

Anderson, A. H. (2013). To the ends of the earth: Pentecostalism and the transformation of world Christianity. Oxford University Press. 187-210.

Anderson, R. (1999). Theological Foundations for Ministry. $2^{\text {nd }}$ Rev. Ed; Edinburgh: T \& T Clark.

Anim, E. K. (2010). The prosperity Gospel in Ghana and the primal imagination. Pentvars Business Journal, 4(3), 67-77.

Anim, E. K. (2021). Who Wants to be a Millionaire?: An Analysis of Prosperity Teaching in the Charismatic Ministries (Churches) in Ghana and Its Wider Impact (Vol. 6). LIT Verlag Münster. 11-12.

Asante, E. (2002). The Call to Serve: A Theological Reflection on Ministry. 24pp.

Boesak, A. A. (1978). Black Theology. London: A.R. Mowbray and Co. Ltd.1978. p. 11.

Brouwer, S., Gifford, P., \& Rose, S. D. (2013). Exporting the American gospel: global Christian fundamentalism. Routledge. 5

Dunn, J. D. (1977). Unity and diversity in the New Testament: An inquiry into the character of earliest Christianity. Scm Press. 106. 
Gathogo, J. (2013). Historical developments of theological education in Eastern Africa-The example of Julius Krapf. Handbook of theological education in Africa, 28-46.

Green, M. (1984). "What Is Evangelism?." The Asbury Journal 39(2), 4.

Hackett, R. (1998). "Charismatic/Pentecostal appropriation of media technologies in Nigeria and Ghana." Journal of Religion in Africa 28 (3), 258-277.

Hazlitt, W. (2004). Martin Luther Table Talk, updated and revised from a translation by William Hazlitt (Gainsville, FL: Bridge-Logos, 2004), 352.

Hollenweger, W. J. (1997). Pentecostalism: Origins and developments worldwide. Hendrickson Publishers. 1-10.

Larbi, E. K. (2001). Pentecostalism: the eddies of Ghanaian Christianity. CPCS.

Meyer, B. (2004) "Christianity in Africa: From African independent to Pentecostal-charismatic churches." Annu. Rev. Anthropol. (33), 447-474.

Morrison, M. 2019. Free Resources: Ministry Means Service, by Michael Morrison Retrieved from https://learn.gcs.edu > mod > page > view

Mugambi, J. N. (1989). The Biblical basis for evangelization: theological reflections based on an African experience. University of Nairobi. Oxford University Press. p.69.

Mumo, P. M. (2013). Sunday schools as the foundation of Christian nurture and their relevance for theological education in Africa. Ilorin Journal of Religious Studies, (IJOURELS) 6 (1), 47-58.

Okolo, C. B. (1991). The liberating role of the Church in Africa today. AMECEAGaba Publ. p. 47.

O'Meara, T. (1983). Theology of ministry (New Jersey, Paulist Press, 1983). p 136.

Pobee, S. J., \& Hallencrentz, C.F. (1986). Variations in Christian Theology in Africa. Nairobi: Uzima Press. p.3

Pobee, S. J. (2013) "Good News turned by native hands, turned by native hatchets and tendered with native earth-A history of theological education in Africa." Handbook of theological education in Africa. p. 13-27.

Pobee, S. J. 1990. Theological education in Africa: quo vadimus? Asempa Publ. 5

Resane, K. (2017). Commercialisation of theological education as a challenge in the NeoPentecostal Charismatic churches. HTS: Theological Studies, 73(3), 1-7.

Resane, K. (2016). The new apostolic reformation: The critical reflections of the ecclesiology of Charles Peter Wagner. HTS Teologiese Studies/Theological Studies, 72(3).

Rowdon, H. H. (1971). "Theological education in historical perspective." Vox Evangelica (7), 75-87.

Tidball, D. J. (1986). Skillful Shepherds: An Introduction to Pastoral Theology Grand Rapids, MI: Zondervan, p.33.

Walls, A. (2013). Theological Education from its Earliest Jewish and African Christian Beginning-some Currents in the Wider History of Christianity. The Handbook of Theological Education in Africa. South Africa: Cluster Publications, p. 1-11.

Walls, A. (1976).'Towards understanding Africa's place in Christian history'in Religion in a Pluralistic Society edited by Pobee, John S. 180-189, Leiden: E.J. Brill, viii.

Warren, R. (1995). The Purpose Driven Church. Grand Rapids: Zondervan, 1995. p. 87.

Werner, D. (2010). "Viability and ecumenical perspectives for theological education in Africa: legacy and new beginnings in Ecumenical Theological Education/World Council of Churches." Missionalia: Southern African Journal of Mission Studies 38 (2), 275-293.

Woodbridge, D. J. (1994). Doing theology in today's world: Essays in honor of Kenneth S. Kantzer. Zondervan. 300-312. 
Wolterstorff, N., \& Stronks, G. G. (2002). Educating for life: Reflections on Christian teaching and learning. C. W. Joldersma (Ed.). Grand Rapids, MI: Baker Academic. 1-40.

Wingate, A. (2005) "Overview of the history of the debate about theological education." International Review of Mission 94(373), 235-247.

\section{APPENDICES}

\section{Appendix 1}

\section{CHRISTIAN SERVICE UNIVERSITY COLLEGE}

Dear Respondent,

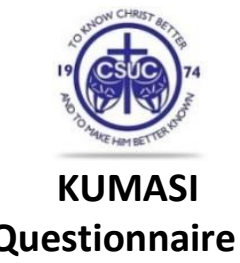

This Questionnaire aims at examining "The Relevance and Practice of Theological Education among Charismatic Churches in Santasi-Heman", Ghana. The research is purely academic in nature and any information obtained from this questionnaire will be confidential. We shall appreciate your cooperation and support.

Please tick and fill where appropriate

\section{Section A: Background Information}

1. Name of Respondent

2. Gender of Respondent:

a) Male

b) Female

3. What is your Title? a) Bishop

b) Reverend c) Pastor d) Apostle e) Prophet) f) $P \square$ bhetess) g) $O \square$ rs (specify)
4. Age of Respondent:
a) Below 25
b) $26-40$
c) $41-50$
d) Above 51

5. What is your highest educational qualification or nearest equivalent?

a) HND
b) Bachelo
c) Master's degree
d) Professional qualification
f) Others (specify)

e) $\mathrm{PhC}$

6. What is your highest level of Theological Education? a) Cert $\square$ ate b ) Diploma

c) Bachelor

c Waster's degree

e $\square$ ofessional qualification

f) म

g) Others (specify)

7. How long have you been working in this Church/Ministry? a) Below 5 ars

8. Specify your position in the organization

b) 6-10 yea $\square$

c) 11-15years

d) $\square$ rears and above 


\section{Section B: Knowledge in Theological Education}

To what extent are your church Ministers/Pastors/leaders knowledgeable in theological education. You are required to tick where appropriate, where (1) = To a very great extent, (2) $=$ To a great extent, $(3)=$ To a moderate extent, $(4)=$ To a little extent, $(5)=$ Not at all.

\begin{tabular}{|c|c|c|c|c|c|c|}
\hline & Statements & 1 & 2 & 3 & 4 & 5 \\
\hline & Knowledge in Theological Education & & & & & \\
\hline 1 & How do you understand the term theological education? & [ ] & [ ] & [ ] & [ ] & [ ] \\
\hline 2 & Did you study theology before starting practical ministry? & [ ] & [ ] & [ ] & [ ] & [ ] \\
\hline 3 & $\begin{array}{l}\text { How knowledgeable are other leaders of your church in } \\
\text { theology? }\end{array}$ & [ ] & [ ] & [ ] & [ ] & [ ] \\
\hline 4 & $\begin{array}{l}\text { Are you familiar with Biblical studies as a basic type of } \\
\text { Christian theology? }\end{array}$ & [ ] & [ ] & [ ] & [ ] & [ ] \\
\hline 5 & $\begin{array}{l}\text { Are you familiar with church history as a subject in } \\
\text { Christian theology? }\end{array}$ & [ ] & [ ] & [ ] & [ ] & [ ] \\
\hline 6 & Do you understand the term Hermeneutics? & [ ] & [ ] & [ ] & [ ] & [ ] \\
\hline 7 & Do you understand the term Exegesis? & [ ] & [ ] & [ ] & [ ] & [ ] \\
\hline 8 & Are you familiar with the term Homiletics? & [ ] & [ ] & [ ] & [ ] & [ ] \\
\hline 9 & Are you familiar with Ministerial Ethics? & [ ] & [ ] & [ ] & [ ] & [ ] \\
\hline
\end{tabular}

To what extent does your church Ministers/Pastors/leaders practice theological education? You are required to tick where appropriate, where $(1)=$ To a very great extent, $(2)=$ To a great extent, $(3)=$ To a moderate extent, $(4)=$ To a little extent, $(5)=$ Not at all.

\begin{tabular}{|c|c|c|c|c|c|c|}
\hline No. & Statement & 1 & 2 & 3 & 4 & 5 \\
\hline & Extent of Practicing theological education & [ ] & [ ] & [ ] & [ ] & [ ] \\
\hline 1 & $\begin{array}{l}\text { Does your church do Bible studies as part of church } \\
\text { programme? }\end{array}$ & [ ] & [ ] & [ ] & [ ] & [ ] \\
\hline 2 & $\begin{array}{l}\text { Does your church do Bible Expositions as part of church } \\
\text { programme? }\end{array}$ & [ ] & [ ] & [ ] & [ ] & [ ] \\
\hline 3 & Is (Exegesis) Bible text studies part of your Bible studies? & [ ] & [ ] & [ ] & [ ] & [ ] \\
\hline 4 & Does your church do Bible Character studies? & [ ] & [ ] & [ ] & [ ] & [ ] \\
\hline 5 & Is your church familiar with teachings on Church History? & [ ] & [ ] & [ ] & [ ] & [ ] \\
\hline 6 & Teaching of Christian Leadership is important in your church & [ ] & [ ] & [ ] & [ ] & [ ] \\
\hline 7 & Does your church teach Theology of Ministry? & [ ] & [ ] & [ ] & [ ] & [ ] \\
\hline 8 & $\begin{array}{l}\text { Does your church contribute to societal development and } \\
\text { transformation? }\end{array}$ & [ ] & [ ] & [ ] & [ ] & [ ] \\
\hline
\end{tabular}


To what extent are your church Ministers/Pastors/leaders making relevance of theological education on practical ministry? You are required to tick where appropriate, where $(1)=$ To a very great extent, $(2)=$ To a great extent, $(3)=$ To a moderate extent, $(4)=$ To a little extent, (5) = Not at all.

\begin{tabular}{|c|c|c|c|c|c|c|}
\hline No. & Statement & 1 & 2 & 3 & 4 & 5 \\
\hline & \multicolumn{6}{|l|}{$\begin{array}{l}\text { Assessing the relevance of theological education on } \\
\text { practical ministry }\end{array}$} \\
\hline 1 & Theological education can promote sound teachings & [ ] & [ ] & [ ] & [ ] & [ ] \\
\hline 2 & Does theological education enhance good ministerial ethics? & [ ] & [ ] & [ ] & [ ] & [ ] \\
\hline 3 & Theological education can influence evangelism and missions & [ ] & [ ] & [ ] & [ ] & [ ] \\
\hline 4 & Can theological education promote church growth? & [ ] & [ ] & [ ] & [ ] & [ ] \\
\hline 5 & $\begin{array}{l}\text { Does theological education inform pastors/leaders/ministers about } \\
\text { church history? }\end{array}$ & [ ] & [ ] & [ ] & [ ] & [ ] \\
\hline 6 & $\begin{array}{l}\text { Theological education can promote societal development and } \\
\text { transformation }\end{array}$ & [ ] & [ ] & [ ] & [ ] & [ ] \\
\hline 7 & $\begin{array}{l}\text { Do Pastors/Ministers/Leaders who have had any form of } \\
\text { theological education preach/teach better than those who have } \\
\text { not had any theological education? }\end{array}$ & [ ] & [ ] & [ ] & [ ] & [ ] \\
\hline
\end{tabular}

\section{Thank you}

\section{Appendix 2}

\begin{tabular}{|c|c|c|c|c|c|c|c|}
\hline \multicolumn{8}{|c|}{ Statistics } \\
\hline & & Gender & Age & Edulevel & Howlong & TEdulevel & Title \\
\hline \multirow[t]{2}{*}{$N$} & Valid & 8 & 8 & 8 & 8 & 8 & 8 \\
\hline & Missing & 0 & 0 & 0 & 0 & 0 & 0 \\
\hline
\end{tabular}

\section{Frequency Table}

Gender

\begin{tabular}{|l|r|r|r|r|}
\hline & Frequency & Percent & Valid Percent & $\begin{array}{c}\text { Cumulative } \\
\text { Percent }\end{array}$ \\
\hline Valid male & 8 & 100.0 & 100.0 & 100.0 \\
\hline
\end{tabular}

Title

\begin{tabular}{|ll|r|r|r|r|}
\hline & & & & \multicolumn{2}{c|}{$\begin{array}{c}\text { Cumulative } \\
\text { Percent }\end{array}$} \\
\hline Valid & Bishop & 1 & 12.5 & 12.5 & 12.5 \\
& Rev & 3 & 37.5 & 37.5 & 50.0 \\
& Pastor & 1 & 12.5 & 12.5 & 62.5 \\
& Apostle & 1 & 12.5 & 12.5 & 75.0 \\
Prophet & 2 & 25.0 & 25.0 & 100.0 \\
Total & 8 & 100.0 & 100.0 & \\
\hline
\end{tabular}




\begin{tabular}{|c|c|c|c|c|c|}
\hline \multicolumn{6}{|c|}{ Age } \\
\hline & & Frequency & Percent & Valid Percent & $\begin{array}{c}\text { Cumulative } \\
\text { Percent }\end{array}$ \\
\hline \multirow[t]{4}{*}{ Valid } & $26-40$ & 4 & 50.0 & 50.0 & 50.0 \\
\hline & $41-50$ & 3 & 37.5 & 37.5 & 87.5 \\
\hline & above 51 & 1 & 12.5 & 12.5 & 100.0 \\
\hline & Total & 8 & 100.0 & 100.0 & \\
\hline
\end{tabular}

Highest Educational level

\begin{tabular}{|ll|r|r|r|r|}
\hline & & & & \multicolumn{2}{c|}{$\begin{array}{c}\text { Cumulative } \\
\text { Percent }\end{array}$} \\
\hline Valid & Diploma & 3 & 37.5 & 37.5 & 37.5 \\
& Bachelor & 1 & 12.5 & 12.5 & 50.0 \\
Master & 1 & 12.5 & 12.5 & 62.5 \\
PhD & 1 & 12.5 & 12.5 & 75.0 \\
Others JHS/SHS & 2 & 25.0 & 25.0 & 100.0 \\
Total & 8 & 100.0 & 100.0 & \\
\hline
\end{tabular}

Number of years working in church/ministry

\begin{tabular}{|ll|r|r|r|r|}
\hline & & & & \multicolumn{2}{c|}{$\begin{array}{c}\text { Cumulative } \\
\text { Percent }\end{array}$} \\
\hline Valid & 6requency & Percent & Valid Percent & 12.5 \\
& 11-15yrs & 1 & 12.5 & 12.5 & 75.0 \\
& $16 y$ rs above & 5 & 62.5 & 62.5 & 100.0 \\
& 2 & 25.0 & 25.0 & \\
\hline
\end{tabular}

Highest level of theological education

\begin{tabular}{|c|c|c|c|c|c|}
\hline & & Frequency & Percent & Valid Percent & $\begin{array}{c}\text { Cumulative } \\
\text { Percent }\end{array}$ \\
\hline \multirow[t]{5}{*}{ Valid } & Certificate & 1 & 12.5 & 12.5 & 12.5 \\
\hline & Diploma & 4 & 50.0 & 50.0 & 62.5 \\
\hline & Bachelor & 2 & 25.0 & 25.0 & 87.5 \\
\hline & others none & 1 & 12.5 & 12.5 & 100.0 \\
\hline & Total & 8 & 100.0 & 100.0 & \\
\hline
\end{tabular}

